\title{
Involvement of NO Generation in Aluminum-Induced Cell Death
}

\author{
Eiko Satoh, Iho Yasuda, Tomoko Yamada, Yasuyuki Suzuki, and Takao Ohyashiki* \\ Department of Clinical Chemistry, Faculty of Pharmaceutical Sciences, Hokuriku University; Kanagawa-machi, \\ Kanazawa 920-1181, Japan. Received January 11, 2007; accepted May 22, 2007; published online May 25, 2007
}

Previously, we have reported that the exposure of PC12 cells to the aluminum-maltolate complex $\left(\mathrm{Al}(\mathrm{maltol})_{3}\right)$ results in decreased cell viability via the apoptotic cell death pathway. In this study, we have used several nitric oxide synthase (NOS) inhibitors and the NO generator diethylenetriamine NONOate (DETA NONOate) to examine whether or not intracellular nitric oxide (NO) generation is involved in the onset mechanism of $\mathrm{Al}$ (maltol) $)_{3}$-induced cell death. Cell viability was assessed by measuring lactate dehydrogenase (LDH) re-

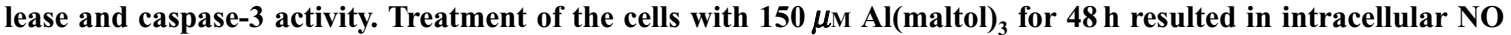
generation. Exposure of the cells to DETA NONOate also induced a marked decrease in cell viability. Pre-treatment of the cells with a general NOS inhibitor or with a selective inducible NOS (iNOS) inhibitor effectively prevented $\mathrm{Al}$ (maltol) ${ }_{3}$-induced cell death. However, a neuronal NOS (nNOS) inhibitor did not exhibit any protective effect against $\mathrm{Al}(\mathrm{maltol})_{3}$-induced cell death. In addition, ascorbic acid markedly inhibited $\mathrm{Al}(\mathrm{maltol})_{3}$ - and DETA NONOate-induced cell death. Based on these results, we discussed the involvement of intracellular NO generation in the onset mechanisms of $\mathrm{Al}(\mathrm{maltol})_{3}$-induced cell death.

Key words aluminum toxicity; nitric oxide; caspase; ascorbic acid

Aluminum (Al) is the third most abundant element in the earth's crust and has been implicated as an etiologic factor in neurological disorders including Alzheimer's disease, ${ }^{1,2}$ Parkinson's dementia syndrome, and dialysis encephalopathy syndrome. ${ }^{3,4)}$ In fact, some evidence supports the selective accumulation of $\mathrm{Al}$ within neurons containing neurofibrillay tangles in patients with Alzheimer's disease and within the aging human brain. ${ }^{1,5)}$ Meiri et al., have also reported that brain $\mathrm{Al}$ concentrations reach submilimolar levels in some encephalopathies. $\left.{ }^{6}\right)$ Several lines of research that use cultured cells and the aluminum-maltolate complex $\left(\mathrm{Al}(\mathrm{maltol})_{3}\right)$, which is a membrane permeable, lipophilic complex of Al, also showed that the exposure of cells such as the Neuro-2a murine neuroblastoma cells, ${ }^{7)}$ human NT2 neuroblastoma cells, ${ }^{8)}$ and $\mathrm{PC} 12$ cells $^{9,10)}$ to the $\mathrm{Al}$ complex results in a decrease in cell viability via the apoptotic cell death pathway. Recently, we have reported that the treatment of PC12 cells with $\mathrm{Al}(\mathrm{maltol})_{3}$ causes a decrease in the levels of the intracellular reduced glutathione depending on the amount of $\mathrm{Al}(\text { maltol })_{3}$ accumulated in the cells. ${ }^{11}$ ) These findings strongly suggested that $\mathrm{Al}$ accumulation in tissues is closely related to the development of neurodegenerative disorders although a causal relationship between $\mathrm{Al}$ and neurodegenerative disorders remains unclear.

$\mathrm{NO}$ is considered to be a modulator and a simple and diffusible free radical. ${ }^{12)}$ It is believed to play an important role in physiological and pathophysiological events in many cellular systems. ${ }^{13-15)}$ Furthermore, it has also been reported that NO concentration increased in the brain during the course of ischemia, Alzheimer's disease, and other degenerative conditions. ${ }^{16-18)}$ Numerous studies in several cell systems have demonstrated that $\mathrm{NO}$ is closely related to cell death mechanisms and plays the role of a mediator. ${ }^{19-23)} \mathrm{A}$ recent study has reported that NO is produced in the mitochondria via $\mathrm{Ca}^{2+}$-dependent mitochondrial NO synthases $(\mathrm{mtNOS}){ }^{24-26)}$ The NO produced in the mitochondria by mtNOS plays the role of a modulator of mitochondrial oxygen consumption and transmembrane potential via a reversible reaction with cytochrome c oxidase. It is well-known that NO rapidly reacts with superoxide anion radicals to form peroxynitrite, which is an oxidant substance producing cytotoxic effects in many cells. ${ }^{14,20)}$

Previously, we have reported that accumulation of $\mathrm{Al}$ (maltol) ${ }_{3}$ in PC12 cells results in apoptotic cell death depending on the intracellular generation of reactive oxygen species (ROS). ${ }^{10)}$ Therefore, it would be interesting to determine if intracellular NO generation is involved in the onset mechanism of Al-mediated-cytotoxicity. Therefore, in the present study, we examined the effects of a $\mathrm{NO}$ generator and $\mathrm{NO}$ synthase inhibitors on $\mathrm{Al}(\mathrm{maltol})_{3}$-induced cell death. Our results suggest that intracellular NO generation may play an important role in the development of cell toxicity associated with $\mathrm{Al}(\text { maltol })_{3}$ treatment.

\section{MATERIALS AND METHODS}

Chemicals 3-Hydroxy-2-methyl-4-pyrone (maltol), $N^{\mathrm{G}}$ nitro-L-arginine methyl ester hydrochloride (L-NAME), $n$ heptyl- $\beta$-D-thioglucoside, and dimethyl sulfoxide were obtained from Wako Pure Chemical (Osaka, Japan). Diaminofluorescein-2 diacetate (DAF-2 DA) was purchased from Daiichi Pure Chemicals Co., Ltd. (Tokyo, Japan). 3-[(3Cholamidopropyl)dimethylammonio]-1-propanesulfonate (CHAPS), Acetyl-Asp-Glu-Val-Asp-7-amido-4-methylcoumarin (Ac-DEVD-AMC), 7-nitroindasole (7-NI), and $\beta$ nicotinamide adenine dinucleotide (reduced form, $\beta$-NADH) were purchased from Sigma (St. Louis, MO, U.S.A.). 2' (4-Hydroxyphenyl)-5-(4-methyl-1-piperazinyl)-2,5'-bi-1Hbenzimidazole (Hoechst 33528) was obtained from Molecular Probes, Inc. (Eugene, OR, U.S.A.). 2-Methyl-2-thiourea sulfate (SMT) and diethylenetriamine NONOate (DETA NONOate) were obtained from Ardrich (St. Louis, MO, U.S.A.) and Cayman (Ann. Arbor, MI, U.S.A.), respectively. All chemicals used were of the purest grade commercially available.

Preparation of $\mathrm{Al}(\text { maltol })_{3} \quad \mathrm{Al}(\text { maltol })_{3}$ was prepared according to the procedure described by Finnegan et $a l^{27)} \mathrm{A}$ stock solution $(25 \mathrm{mM})$ of $\mathrm{Al}(\text { maltol })_{3}$ was prepared in deion- 
ized water and sterilized using a 0.22 -mm filter.

Cell Culture The PC12 cells were mainly cultured in 35-mm dishes coated with poly-D-lysine at a density of approximately $3.5 \times 10^{5}$ cells $/ \mathrm{ml}$; the medium used was Dulbecco's modified Eagle medium supplemented with 5\% fetal bovine serum and $5 \%$ horse serum at $37^{\circ} \mathrm{C}$ under $95 \%$ air $/ 5 \% \mathrm{CO}_{2}$. The cells were allowed to develop for $24 \mathrm{~h}$ before exposure to $\mathrm{Al}(\text { maltol })_{3}(150 \mu \mathrm{M})$ for $48 \mathrm{~h}$ or DETA NONOate $(250 \mu \mathrm{M})$ for $18 \mathrm{~h}$. On the other hand, the control cells were cultured in the presence of maltol in quantities that was three times the quantity of $\mathrm{Al}(\text { maltol })_{3}$ employed. Morphological changes in the cells were examined throughout the course of the experiment using a phase-contrast microscope (Olympus IX 70-S8F microscope).

Determination of NO Production NO was detected using the fluorescence dye DAF-2 DA, according to a previously published paper. $^{28)}$ Cells were incubated with $10 \mu \mathrm{M}$ DAF-2 DA for $30 \mathrm{~min}$ at $37^{\circ} \mathrm{C}$. The reaction was terminated by the addition of L-NAME at a final concentration of $5 \mathrm{mM}$. The cells were washed twice and resuspended with in $\mathrm{Ca}$, $\mathrm{Mg}$ free-phosphate buffered saline (CMF-PBS) containing $5 \mathrm{~mm}$ L-NAME, respectively, and the fluorescence of the cell suspension was measured. The excitation and emission wavelengths were 495 and $515 \mathrm{~nm}$, respectively. The fluorescence intensity (FI; arbitrary unit) was expressed as the value per mg of protein.

Cell Viability Measurement Cell viability was assessed by lactate dehydrogenase $(\mathrm{LDH})$ release measurement. The reaction was initiated by the addition of an aliquot $(250 \mu \mathrm{l})$ of the culture medium to an assay medium $(750 \mu \mathrm{l})$ containing $\beta$-NADH $(88 \mu \mathrm{g} / \mathrm{ml})$, pyruvate $(100 \mu \mathrm{M})$, and $100 \mathrm{~mm}$ phosphate buffer ( $\mathrm{pH} 7.5)$. The rate of change in absorbance of NADH at $340 \mathrm{~nm}\left(\Delta \mathrm{A}_{340}\right)$ was measured at 1 min using the Hitachi spectrophotometer U2810. The data were expressed as values relative $(\%)$ to the total $\mathrm{LDH}$ that could be released using $1 \% n$-heptyl- $\beta$-D-thioglucoside. ${ }^{10)}$

Caspase Activity Assay The PC12 cells $\left(1 \times 10^{7}\right)$ were washed twice with CMF-PBS and then suspended in an icecold 50-mm potassium phosphate buffer $(\mathrm{pH} 7.5)$. To prevent the non-specific cleavage of proteins, cell lysis was performed by two cycles of freezing and thawing at $4{ }^{\circ} \mathrm{C}$. The mixture was centrifuged at $13000 \times \boldsymbol{g}$ for $10 \mathrm{~min}$ at $4{ }^{\circ} \mathrm{C}$, and the supernatant obtained was stored at $-80^{\circ} \mathrm{C}$ until use in the caspase activity assay. The reaction was initiated by the addition of Ac-DEVD-AMC (at a final concentration of $50 \mu \mathrm{M})$ to the reaction mixture containing $50 \mathrm{~mm}$ Tris/ $\mathrm{HCl}$ buffer (pH7.5), 0.1\% CHAPS, $10 \mathrm{~mm}$ dithiothreitol, and the cell lysate $\left(50 \mu \mathrm{g}\right.$ protein) at $37^{\circ} \mathrm{C}$. The total volume of the assay medium was $500 \mu \mathrm{l}$. After $30 \mathrm{~min}$, the reaction was terminated by the addition of the stop solution $(50 \mu \mathrm{l})$ comprising $175 \mathrm{~mm}$ acetic acid and 1\% sodium acetate. The AMC levels were measured by using the Hitachi fluorescence spectrophotometer F-4500 with the excitation and emission wavelengths at 380 and $400 \mathrm{~nm}$, respectively. The enzyme activity was expressed as $\mathrm{FI} / \mathrm{mg}$ protein/min.

Assay for Nuclear Condensation The cells were fixed using a $10 \%$ formalin neutral phosphate buffer solution $(\mathrm{pH}$ 7.4) for $5 \mathrm{~min}$ at room temperature. After washing with distilled water, the cells were stained for $5 \mathrm{~min}$ with Hoechst 33258 at a concentration of $8 \mu \mathrm{g} / \mathrm{ml}$. The cells were washed again with distilled water. Dye fluorescence was measured using the Olympus IX 70 fluorescence microscope with the excitation and emission wavelengths at 340 and $510 \mathrm{~nm}$, respectively.

Protein Determination Protein concentration was determined by the procedure described by Lowry et al. using bovine serum albumin as the standard. ${ }^{29)}$

Statistical Analysis Data are presented as the mean士 S.E.M. values of three different experiments. The data were analyzed by an ANOVA Scheffe's multiple $t$ test.

\section{RESULTS AND DISCUSSION}

NO Generation by $\mathbf{A l}(\text { maltol })_{3}$ Treatment To determine the relationship between cell death by $\mathrm{Al}(\text { maltol) })_{3}$ treatment and intracellular NO generation, we measured the fluorescence of cells labeled with the fluorescent dye DAF-2 DA.

As shown in Fig. 1, a 48-h exposure of the cells to $150 \mu \mathrm{M}$ $\mathrm{Al}(\text { maltol })_{3}$ resulted in an increase in fluorescence intensity of the dye incorporated into the cells. Development of dye fluorescence depends on the formation of a fluorescent product as a result of the interaction of the dye with the NO generated. ${ }^{28)}$ Hence, this result indicates that treatment of the cells with $\mathrm{Al}$ (maltol) $)_{3}$ caused intracellular $\mathrm{NO}$ generation. This possibility was further confirmed by a complete inhibition of $\mathrm{Al}$ (maltol) ${ }_{3}$-induced fluorescence increase in the presence of $5 \mathrm{~mm}$ L-NAME. On the other hand, the dye fluorescence of the control cell was not affected by the addition of L-NAME (FI/mg protein of control without and with LNAME were $0.53 \pm 0.02$ and $0.55 \pm 0.01$, respectively).

Effect of NO on Cell Viability The PC12 cells were exposed to $250 \mu \mathrm{m}$ DETA NONOate to assess the possible toxic effects of NO on cell viability.

As shown in Table 1, treatment of the cells with an exogenous NO donor for $18 \mathrm{~h}$ facilitated LDH release and resulted in an increase in caspase- 3 activity.

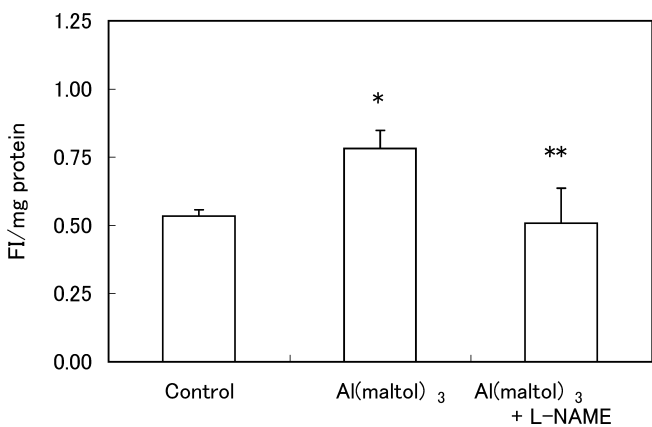

Fig. 1. Effect of $\mathrm{Al}(\text { maltol })_{3}$ Treatment on NO Generation in PC12 Cells

The cells were exposed to $150 \mu \mathrm{M} \mathrm{Al}(\text { maltol })_{3}$ for $48 \mathrm{~h}$ in the absence and presence of $5 \mathrm{~mm}$ L-NAME. Values are expressed as means \pm S.E.M. for $4-8$ independent measurements. $* p<0.05 v s$. Control. $* * p<0.05 v s$. $\mathrm{Al}(\text { maltol })_{3}$ treatment.

Table 1. Changes in LDH and Caspase-3 Activities by NONOate Treatment

\begin{tabular}{ccc}
\hline \hline & LDH release $(\%)$ & $\begin{array}{c}\text { Caspase-3 activity } \\
\text { (FI/min/mg protein) }\end{array}$ \\
\hline Control cells & $8.7 \pm 0.5$ & $67.0 \pm 1.0$ \\
Treated cells & $31.8 \pm 3.5^{*}$ & $851 \pm 102.7^{*}$ \\
\hline
\end{tabular}

The cells were exposed to $250 \mu \mathrm{M}$ DETA NONOate for $18 \mathrm{~h}$. Values are expressed as means \pm S.E.M. for three independent measurements. $* p<0.05 v$ s. control. 


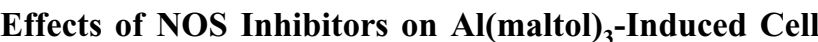
Death Next, we examined the effects of several NOS inhibitors, such as L-NAME and SMT, on cell death by treating the cells with $150 \mu \mathrm{M} \mathrm{Al}(\text { maltol })_{3}$ for $48 \mathrm{~h}$.

As shown in Fig. 2, a 48-h exposure to $150 \mu \mathrm{M} \mathrm{Al}$ (maltol) resulted in marked facilitation of $\mathrm{LDH}$ release from the cells (Fig. 2A) and activation of caspase-3 activity (Fig. 2B). In contrast, pretreatment of the cells with L-NAME, which is a general competitive inhibitor of NOS, ${ }^{30)}$ effectively inhibited caspase- 3 activation and $\mathrm{Al}$ (maltol) $)_{3}$-induced $\mathrm{LDH}$ release in a concentration-dependent manner. However, the extents of inhibitory effect of L-NAME against LDH release and caspase- 3 activity were different in each other. This suggests the possibility that mechanisms of response reflection in these parameters are different, although the exact reason for the discrepancy is unclear at present. On the other hand, treatment of the cells with L-NAME alone did not affect these parameters.

Furthermore, it is clear that L-NAME also protected $\mathrm{Al}$ (maltol) $)_{3}$-induced changes in cell and nuclear morphology (Figs. 3A, B). These results also suggest that NO is involved in the onset mechanism of $\mathrm{Al}\left(\right.$ maltol) ${ }_{3}$-induced cell death. Next, we examined the effects of SMT, a selective iNOS inhibitor, ${ }^{31)}$ and 7-NI, a selective nNOS inhibitor, ${ }^{32)}$ on the cell viability.

As shown in Fig. 4, pretreatment of the cells with SMT resulted in effective protection against LDH release (Fig. 4A) and caspase-3 activity (Fig. 4B). Treatment of the cells with only SMT under the same conditions did not affect these parameters. On the other hand, the extent of LDH release $(\%)$ in $\mathrm{Al}(\mathrm{maltol})_{3}$-treated cells without and with $100 \mu_{\mathrm{M}} 7-\mathrm{NI}$ was 50.8 \pm 3.4 and 55.2 \pm 1.4 , respectively; this indicates that 7 -NI did not protect against $\mathrm{Al}$ (maltol) ${ }_{3}$-induced cell damage.

In a preliminary experiment, we found that $\mathrm{Al}(\text { maltol })_{3}$ treatment of the cells did not induce an appreciable increase of iNOS protein expression (data not shown). Szabo et al. have demonstrated that SMT plays as a direct competitive inhibitor of the activity of iNOS. ${ }^{31)}$ From these findings, it

A

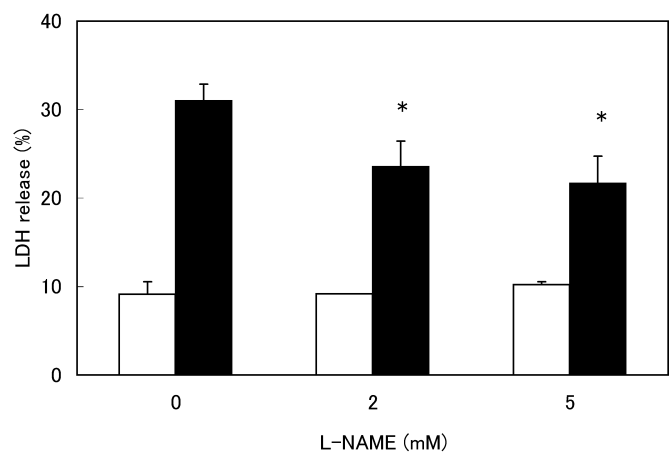

B

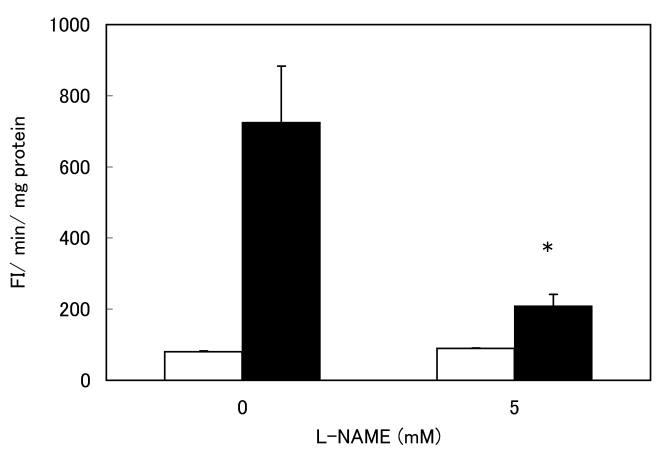

Fig. 2. Effects of L-NAME on Al(maltol) $)_{3}$-Induced LDH Release (A) and Caspase-3 Activation (B)

The cells were preincubated with L-NAME (2 and $5 \mathrm{~mm}$ in A and $5 \mathrm{~mm}$ in B) for $30 \mathrm{~min}$ before $48-\mathrm{h}$ exposure to $\mathrm{Al}(\mathrm{maltol})_{3}(150 \mu \mathrm{M})$. Symbols: $\square$, control; $\mathrm{Al}(\text { maltol })_{3}$ treatment. Values are expressed as means \pm S.E.M. for three independent measurements. $* p<0.05 v s$. $\mathrm{Al}(\mathrm{maltol})_{3}$ treatment.

\section{A}
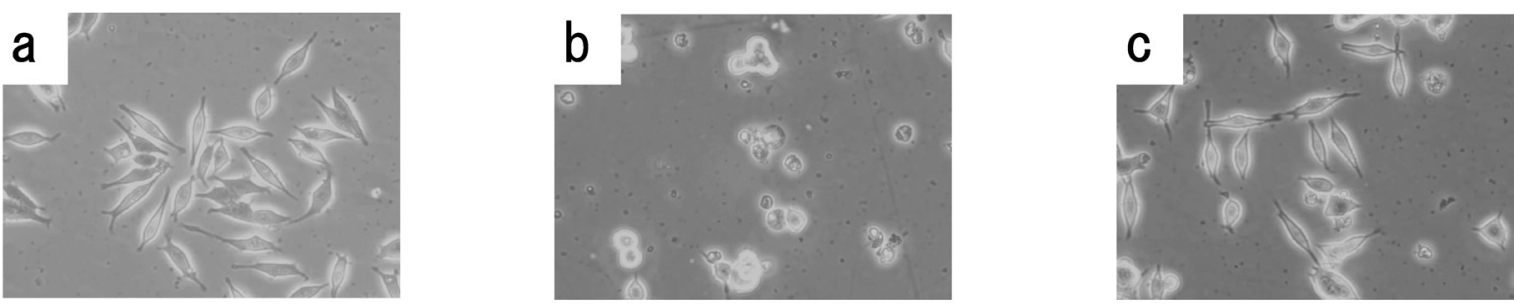

B
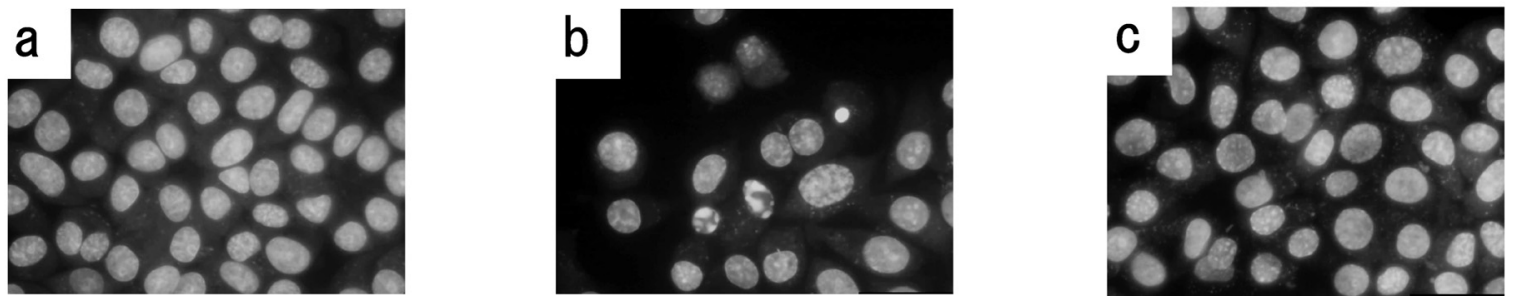

Fig. 3. Effect of L-NAME on Cell Morphology (A) and the Fluorescence Image of Hoechst-Stained Cells (B)

The experimental conditions are the same as those described in the legend of Fig. 2. a, control; b, $\mathrm{Al}(\mathrm{maltol})_{3}$ treated; c, $\mathrm{Al}(\mathrm{maltol})_{3}+5 \mathrm{mM} \mathrm{L}-\mathrm{NAME}$ treated. 
A

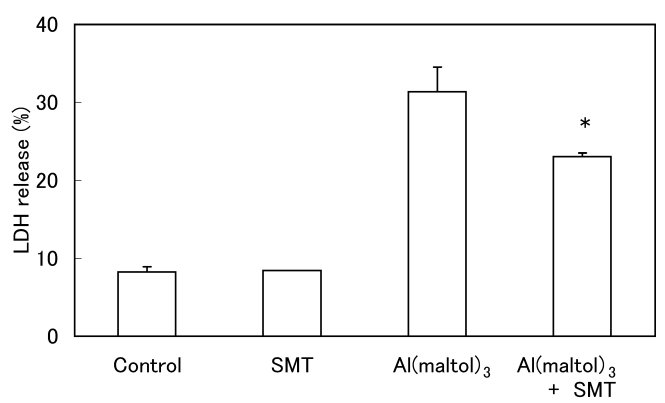

B

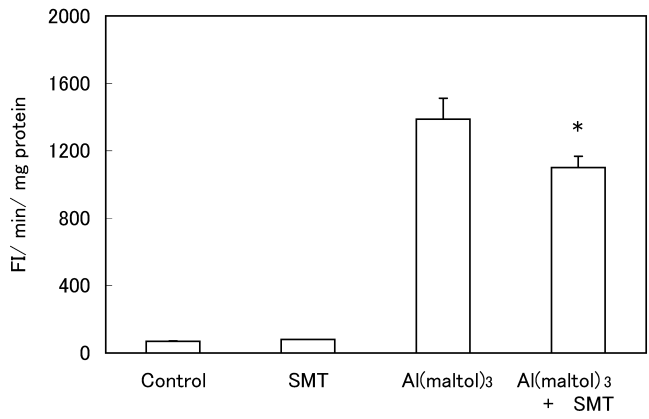

Fig. 4. Effect of SMT on $\mathrm{Al}(\mathrm{maltol})_{3}$-Induced LDH Release and Caspase3 Activation

The experimental conditions are the same as those described in the legend of Fig. 2, except for the use of SMT (5 mM) instead of L-NAME. (A) LDH release and (B) Caspase- 3 activity. Values are expressed as means \pm S.E.M. for three independent measurements. $* p<0.05 v s . \mathrm{Al}(\mathrm{maltol})_{3}$ treatment

seems likely that the inhibitory effect of SMT against $\mathrm{Al}(\mathrm{maltol})_{3}$-induced cell death may be due to inhibition of iNOS activity rather than inhibition of the protein expression. Together these results and findings, we speculated that iNOS, but not nNOS, plays an important role in the onset mechanisms of $\mathrm{Al}\left(\right.$ maltol) ${ }_{3}$-induced cell death.

Effects of Ascorbic Acid Previously, we have reported that $\mathrm{NAC}$ effectively protected $\mathrm{Al}(\text { maltol })_{3}$-induced cell death by increasing the concentration of intracellular reduced glutathione. ${ }^{11)}$ To further confirm the protective effects of an antioxidant on $\mathrm{Al}(\mathrm{maltol})_{3}$-induced cell death, we employed ascorbic acid in the present study.

Figures 5 and 6 show the effects of ascorbic acid on $\mathrm{Al}(\text { maltol })_{3^{-}}$and DETA NONOate-induced cell death and cell morphology. As shown in Fig. 5, A and B, it is clear that both $\mathrm{Al}(\text { maltol })_{3}$ - and DETA NONOate-induced LDH release are almost completely prevented by ascorbic acid present in the culture medium. A similar protective effect of ascorbic acid was also observed against $\mathrm{Al}(\mathrm{maltol})_{3}$ - and $\mathrm{NO}$-induced cell morphological changes (Fig. 6).

Yamamoto et al. have also reported that ascorbic acid effectively protects against NOR3-induced cell death of PC12 cells; this protection is better than that provided by reduced glutathione and cysteine. ${ }^{22)}$ In addition, Desole et al. have demonstrated that manganese-induced apoptosis of PC12 cells, which is related to oxidative stress, is completely inhibited by ascorbic acid. ${ }^{33)}$ These results and findings suggest that cell death induced by $\mathrm{Al}(\mathrm{maltol})_{3}$ and DETA NONOate is involved in intracellular ROS generation. In a previous paper, we have reported that the cytotoxic effect of $\mathrm{Al}(\text { maltol })_{3}$ depends on the concentration of intracellular
A

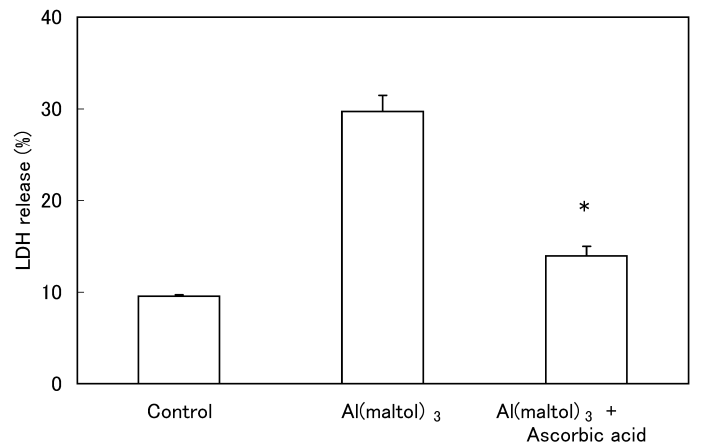

B

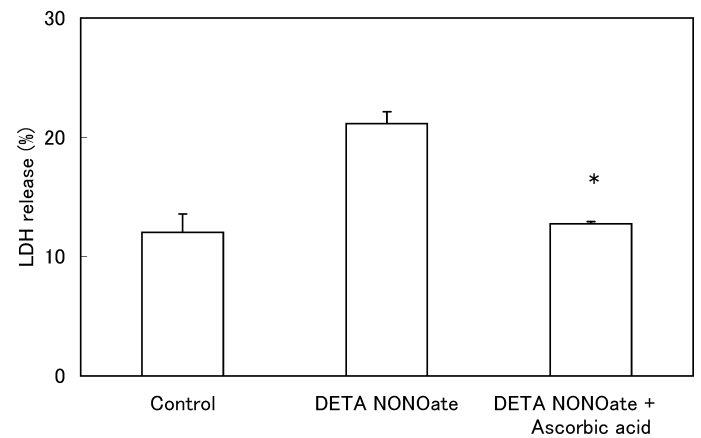

Fig. 5. Protective Effect of Ascorbic Acid against $\mathrm{Al}(\text { maltol })_{3}$ - and NOInduced LDH Release

The cells were preincubated with $1 \mathrm{~mm}$ ascorbic acid for $30 \mathrm{~min}$ before a 48 -h exposure to $\mathrm{Al}$ (maltol) $)_{3}$, or an 18-h exposure to DETA NONOate. The concentrations of $\mathrm{Al}(\text { maltol })_{3}$ and DETA NONOate were 150 and $250 \mu \mathrm{M}$, respectively. Values are expressed as means \pm S.E.M. for three independent measurements. $* p<0.05$ vs. $\mathrm{Al}(\text { maltol })_{3}$ treatment.
$\mathrm{Al}(\mathrm{mal} \text { tol) })_{3}$
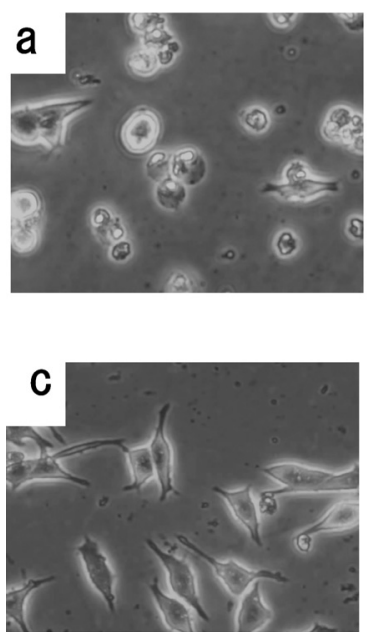

\section{DETA NONOate}
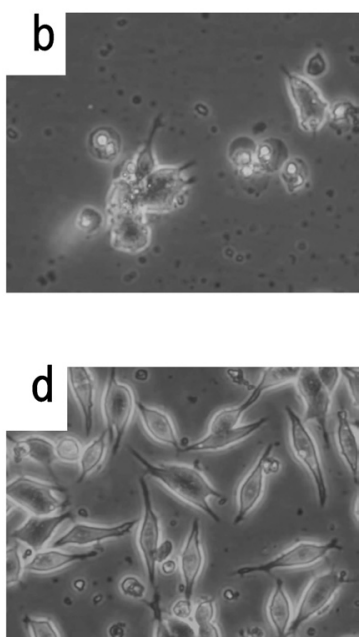

Fig. 6. Protective Effects of Ascorbic Acid on Cell Morphological Changes

The experimental conditions are the same as those described in the legend of Fig. 5. $\mathrm{a}$ and $\mathrm{b}$, without ascorbic acid; $\mathrm{c}$ and $\mathrm{d}$, with $1 \mathrm{~mm}$ ascorbic acid.

$\mathrm{Al}(\text { maltol })_{3}$ incorporated into the cells. ${ }^{10)}$

Based on these findings, it is speculated that intracellular NO generation that is related to $\mathrm{Al}(\mathrm{maltol})_{3}$ accumulation in cells plays an important role in the onset mechanism of $\mathrm{Al}$ (maltol) ${ }_{3}$-induced cell death. Further, it seems that these data give us an important clue for the analyzing mechanisms 
concerning the onset of Al-mediated neurodegenerative diseases.

Acknowledgments This work was supported by a grant from the special research fund of Hokuriku University.

\section{REFERENCES}

1) Perl D. P., Brody A. R., Science, 208, 297-299 (1980).

2) Harrington C. R., Wischik C. M., McArthur F. K., Taylor G. A., Edwardson J. A., Candy J. M., Lancet, 343, 993-997 (1994).

3) Gajdusek D. C., Salazar A. M., Neurology, 32, 107-126 (1982).

4) Deloncle R., Guillard O., Neurochem. Res., 15, 1239-1245 (1990).

5) Markesbery W. R., Ehmann W. D., Hossain T. I., Alauddin M., Goodin D. T., Ann. Neurol., 10,511-516 (1981).

6) Meiri H., Banin E., Roll M., Rousseau A., Prog. Neurobiol., 40, 89121 (1993).

7) Abreo K., Abreo F., Sella M. L., Jain S., J. Neurochem., 72, 20592064 (1999).

8) Griffioen K. J., Ghribi O., Fox N., Savory J., DeWitt D. A., Neurotoxicology, 25, 859-867 (2004).

9) Tsubouchi R., Htay H. H., Murakami K., Haneda M., Yoshino M., Biometals, 14, 181-185 (2001).

10) Ohyashiki T., Satoh E., Okada M., Takadera T., Sahara M., Toxicology, 176, 195-207 (2002)

11) Satoh E., Okada M., Takadera T., Ohyashiki T., Biol. Pharm. Bull., 28, 941-946 (2005).

12) Schmidt H. H., Walter U., Cell, 78, 919-925 (1994).

13) Garthwaite J., Trends Neurosci., 14, 60-67 (1991).

14) Lipton S. A., Choi Y. B., Pan Z. H., Lei S. Z., Chen H. S., Sucher N. J., Loscalzo J., Singel D. J., Stamler J. S., Nature (London), 364, 626632 (1993).

15) Nowicki J. P., Duval D., Poignet H., Scatton B., Eur. J. Pharmacol., 204, 339-340 (1991).
16) Smith M. A., Richey Harris P. L., Sayre L. M., Beckman J. S., Perry G., J. Neurosci., 17, 2653-2657 (1997).

17) Bolanos J. P., Almeida A., Stewart V., Peuchen S., Land J. M., Clark J. B., Heales S. J., J. Neurochem., 68, 2227-2240 (1997).

18) Torreilles F., Salman-Tabcheh S., Guerin M., Torreilles J., Brain Res. Rev., 30, 153-163 (1999).

19) Dawson V. L., Dawson T. M., Bartley D. A., Uhl G. R., Snyder S. H., J. Neurosci., 13, 2651-2661 (1993).

20) Estevez A. G., Radi R., Barbeito L., Shin J. T., Thompson J. A., Beckman J. S., J. Neurochem., 65, 1543-1550 (1995).

21) Hu J., Van Eldik L. J., J. Neurochem., 69, 2294-2301 (1997).

22) Yamamoto T., Yuyama K., Nakamura K., Kato T., Yamamoto H., Eur. J. Pharmacol., 397, 25-33 (2000).

23) Bielarczyk H., Jankowska A., Madziar B., Matecki A., Michno A., Szutowicz A., Neurochem. Int., 42, 323-331 (2003).

24) Boveris A., Arnaiz S. L., Bustamante J., Alvarez S., Valdez L., Boveris A. D., Navarro A., Methods Enzymol., 359, 328-339 (2002).

25) Ghafourifar P., Cadenas E., Trends. Pharmacol. Sci., 26, 190-195 (2005).

26) Ghafourifar P., Sen C. K., Front. Biosci., 12, 1072-1078 (2007).

27) Finnegan M. M., Retting S. J., Orvig C., J. Am. Chem. Soc., 108 5033-5035 (1986).

28) Kojima H., Nakatsubo N., Kikuchi K., Kawahara S., Kirino Y., Nagoshi H., Hirata Y., Nagano T., Anal. Chem., 70, 2446-2453 (1998).

29) Lowry O. H., Rosebrough N. J., Farr A. L., Randall R. J., J. Biol. Chem., 193, 265-275 (1951).

30) Gray G. A., Schott C., Julou-Schaeffer G., Fleming I., Parratt J. R., Stoclet J. C., Br. J. Pharmacol., 103, 1218-1224 (1991).

31) Szabo C., Southan G. J., Thiemermann C., Proc. Natl. Acad. Sci. U.S.A., 91, 12472-12476 (1994).

32) Katsuki H., Yamamoto R., Nakata D., Kume T., Akaike A., J. Pharm. Sci., 94, 77-80 (2004).

33) Desole M. S., Sciola L., Delogu M. R., Sircana S., Migheli R., Neurosci. Lett., 209, 193-196 (1996). 